\title{
The Impact of E-Media on Customer Purchase Intention
}

\author{
Mehmood Rehmani, Muhammad Ishfaq Khan \\ Department of Management Sciences \\ Mohammad Ali Jinnah University \\ Islamabad Pakistan
}

\begin{abstract}
In this research paper, authors investigated the social media (e-discussion, websites, online chat, email etc) parameters that have effect over the customers buying decisions. The research focused on the development of research model to test the impact of social media on the customer purchase intention. The literature review done to explore the work done on social media. The authors identify the problem and defined the objectives of the studies. In order to achieve them, a research model is proposed that followed by the development of research hypotheses to testify the model.
\end{abstract}

Key words: - e-discussion; e-mail; website; online chat;

\section{INTRODUCTION}

The media that describes a variety of new sources of online information that are created, initiated, circulated and used by consumers intent on educating each other about products, brands, services, personalities, and issues is call social media [4]. Toivonen [46] termed it as an interaction of people to create, share, exchange and commenting contents in networks and virtual communities. By 1979, Tom Truscott and Jim Ellis of Duke University, created the Usenet, a discussion system that permitted Internet users to post messages. According to Kaplan \& Haenlein [27], the era of Social Media probably started about 20 years earlier, when Bruce and Susan Abelson developed "Open Diary," an early social networking website that brought the online diary writers into one community. Terminology of "weblog" was coined at the same time, and truncated as "blog" a year later when a blogger transformed the noun "weblog" into the sentence "we blog." The growing access and availability of Internet further added to the popularity of this concept, which lead to the creation of social networking websites such as MySpace (in 2003) and Facebook (in 2004). This, in turn, coined the term "Social Media," and contributed to the eminence it has today [27].

\section{LITERATURE REVIEW}

Social media encompasses a wide range of online, wordof-mouth forums including blogs [24], company sponsored discussion boards and chat rooms, Consumer-to-consumer email, consumer product or service ratings websites and forums, Internet discussion boards and forums, moblogs (sites containing digital audio, images, movies, or photographs), and social networking websites, to name a few $[27,34,38]$.

Given the fast changes in the communication system brought about by participative social media and internet [44], the better understanding of these technologies is important [33]. The increasing number of personal wireless devices such as internet connected cellphones, communication scientists anticipate the popularity of social networking websites to grow worldwide [14, 22, 27, 47]. Nielsen Net ratings (2006) reported that the number of users of top 10 social networking sites in U.S. grew from 46.8 million to 68.8 million users during one year.

The use of social media has better reach and impact [33, 44] on younger generation. Nancy [33] found relatively low penetration in the population aged 55 and older which suggests that it is not yet an appropriate time to utilize social media for this age group. Spending time on social networking sites appears to be part of young adults' daily activities [17, 20] and an average 30 minutes Facebook usage has been reported. One of the study found that about half of twelve to seventeen year olds $\log$ on daily at social networking site: $22 \%$ logged on several times per day, $26 \%$ once a day, $17 \%$ three to five days perweek, $15 \%$ one or two days per week, and only twenty percent every few weeks or less [30]. However, Nancy (2009) predicted a continuing increase in utilization of social media across all groups and generations in the coming years.

According to an article published in Pakistan Today, based on marketing managers' opinions, the trend of marketing is changing in Pakistan and typical advertisements are not yielding the desired results. Companies including Wi-tribe Pakistan, Pakistan International Airlines (PIA), Sooper biscuits and Haier Pakistan have so far effectively used the technique of digital marketing, whereas various fans of these products have also started using them. Wi-tribe Marketing Manager told Pakistan Today that these techniques have proved to be quite cost-effective whereas their targeted market base was also in urban areas therefore Internet was the best way to spread their messages. Wi-tribe has gained a lot from digital marketing and fans of Wi-tribe's Facebook page were now around 19,000 [18].

Social Networking Websites including Facebook and twitter are being used by various multinational companies in Pakistan in order to convey their messages using word of mouth technique.

Businesses are witnessing an explosion of Internet-based messages and information [29] transmitted through social media [18]. They have become a major factor in influencing various aspects of consumer behavior [41]. Unfortunately, the popular business press and academic literature offers marketing managers very little guidance for incorporating social media into their IMC strategies [31]. Therefore, many 
managers lack a full appreciation for social media's role in the company's promotional efforts. Even though social media is magnifying the impact consumer-to-consumer conversations have in the marketplace, importance of these conversations has not yet been recognized [31].

Since its appearance in marketing research, purchase intention has been the subject of great attention in the academic environments. Customer behavioral intentions are considered as signals of actual purchasing choice, thus are desirable to be monitored [51]. A study on sentiment analysis of online forums and product reviews exhibited that they influence individual's purchase decisions [48].

Intention to buy is the buyer's forecast of which brand he will choose to buy. It has been used extensively in predicting the purchases of durable goods. Intention to buy may be characterized as response short of actual purchase behavior.

A survey of more than 600 youth respondents, $51 \%$ of whom had done online purchases in the past year) established that nearly $40 \%$ learned about the product online, but bought at a physical place or a store, whereas, only $9.3 \%$ began and ended their search online. When asked, where they would prefer to shop, nearly $75 \%$ chose a store over online. Across the field, consumers are combining different channels and approaches, searching online to buy everything in between.

The rapid explosion of social media has melted away the barriers to the flow of information and yet the consequences have barely been felt. Marketing to the Facebook generation will not be confined to harnessing the digital channels, it will change the every way the firm communicates [9] to achieve its objectives. Internet has made it easier than before for marketers to communicate directly with consumers and target audiences, it's of much importance that marketers dramatically alter the PR and marketing strategy to maximize the effectiveness of the direct consumer communication means [42].

Jerry Wind was an early champion of digital marketing, highlighting the revolutionary changes of the Internet on consumer behavior, marketing and business strategy. He urged executives to consider the potential of this new technology to transform their businesses.

Mobile Social Media applications are expected to be the main driver of this evolution, soon accounting for over $50 \%$ of the market (Kaplan \& Heinlein, 2010). Kaplan \& Heinlein further states that in India, mobile phones outnumbered PCs by 10 to 1 . Whereas, in Thailand, only 13 percent of the population owns a computer, while $82 \%$ have access to a mobile phone.

Pew Research Center, a Washington-based think tank, estimates that by 2020, a mobile device will be the primary Internet connection tool for majority of the people round the globe. Social Media applications mobile is likely to attract a currently unexploited base of new users. Even if per capita spending in developing countries may be low, vast population numbers make them relevant for virtually any business entity
[27]. Telecom sector is seeing exorbitant growth in Pakistan. The sector is said to be growing at a fast pace yearly (Pakistan Telecommunication Authority). Mobile subscribers are more than 100 million as of Oct 2010. In fact, Pakistan has the highest mobile penetration rate in the South Asian region [50].

This study intends to explore the impact of social media on purchase intention of mobile phone customers in Pakistan. In view of the growing number of cell phone users, the factors that influence the purchase intention of customers need to be explored. Social Media is being considered playing an important role in customer buying decisions, however little studies have explored its impact over the customer purchase intention. Our study aimed at measuring the impact of social media on customers in Pakistan.

\section{StATEMENT OF THE PROBLEM}

In view of the growing number of internet users, the factors of social media that influence the purchase intention of customers need to be explored. Social Media is being considered playing an important role in customer buying decisions, however little studies have explored its impact over the customer purchase intention. This study intends to explore the impact of social media on purchase intention of mobile phone customers in Pakistan.

\section{RESEARCH OBJECTIVES}

The objectives of this research are twofold:

1- to identify the potential of social media for consideration as a hybrid component of the promotional mix and therefore incorporation as an integral part of IMC strategy.

2- to sensitize the marketing managers on shaping the consumer-to-consumer conversations at various social media tools, which are now driving the marketplace to a greater extent (Lefebvre, 2007; Ellison, 2007; Nancy, 2009 and Tiffany, 2009) than ever before.

\section{THEORETICAL FRAMEWORK}

The literature shows that social media construct include eWOM and Seller created information which cause impact on customer's purchase intention. These two variables have been found associated with information acquisition and perceived quality which lead to change in purchase intention of a customer. Information acquisition also proved associated with perceived quality which is a mixture of service and product quality. In view of the above, the following variables have been identified from literature :

1- Electronic Word of Mouth

2- Seller created online information

3- Information Acquisition

4- Perceived Quality (Combination of Product and Service Quality)

5- Purchase Intention

The proposed research model is as under: 


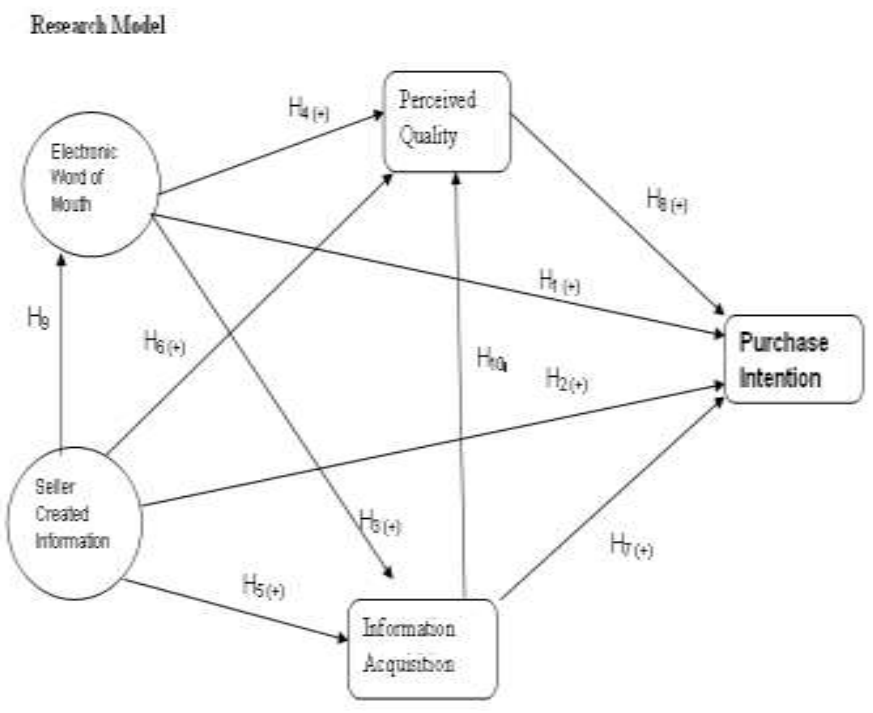

VI. RESEARCH HYPOTHESES

The following hypotheses have been developed to testify the model:

$\mathrm{H}_{1}$ Electronic word of mouth has positive impact on purchase intention

$\mathrm{H}_{2}$ Seller created information has positive impact on purchase intention

$\mathrm{H}_{3}$ Electronic word of mouth has positive impact on perceived quality.

$\mathrm{H}_{4}$ Electronic word of mouth has positive impact on information acquisition.

$\mathrm{H}_{5}$ Seller created information has positive impact on information acquisition.

$\mathrm{H}_{6}$ Seller created information has positive impact on perceived quality.

$\mathrm{H}_{7}$ Information acquisition positively impacts purchase intention of customers.

$\mathrm{H}_{8}$ Perceived quality positively impacts purchase intention of customers.

$\mathrm{H}_{9}$ Perceived quality has association with information acquisition.

$\mathrm{H}_{10}$ Seller created information has association with Electronic word of mouth.

\section{ACKNOWLEDGMENT}

We are thankful to Prof. Arif Vaseer, Mohammad Ali Jinnah University and Mr. Khurram Shahzad, Assistant Professor, Riphah International University for their guidance and support in the completion of research work.

\section{REFERENCES}

[1] Ahn , Y.-Y., Han, S., Kwak, H., Moon, S. and Jeong, H. (2007), "Analysis of topological characteristics of huge online social networking services", Proceedings of the 16th International Conference on World Wide Web, Banff,ACMPress, New York, NY, pp. 835-44.

[2] Amato, Paul R. and Ruth Bradshaw (1985), "An Exploratory Study of People's Reasons for Delaying or Avoiding Helpseeking," Australian Psychologis, 20 (March), 21-31.
[3] Bansal, H. S., Irving, G. P., \& Taylor, S. F. (2004). A three-component model of customer commitment to service providers. Journal of the Academy of Marketing Science, 32(3), 234-250.

[4] Blackshaw, P. and Nazzaro, M. (2004). "Consumer-Generated Media (CGM) 101: Word-of-mouth in the age of the Web fortified consumer", at http://www.nielsenbuzzmetrics.com/whitepapers (accessed: December 11,2008

[5] Boone, L. E., \& Kurtz, D. L. (2007). Contemporary marketing (13th ed.). Mason, $\mathrm{OH}$ : Thomson/South-Western.

[6] C. Anderson. The Long Tail: Why the Future of Business Is Selling Less of More. Hyperion, July 2006.

[7] C. Sang-Hun. To outdo Google, Naver taps into Korea's collective wisdom. International Herald Tribune, July 42007.

[8] Catherine Dwyer, Starr Hiltz \& Katia Passerini (2007), "Trust and Privacy Concern Within Social Networking Sites: A Comparison of Facebook and MySpace", Americas Conference on Information Systems (AMCIS).

[9] Danny Meadows-klue (2008), "Falling in Love 2.0: Relationship Marketing for the Facebook Generation", Journal of Direct, Data and Digital Marketing Practice, 245-250.

[10] Della Lindsay J, Eroglu Dogan, Bernhardt Jay M, Edgerton Erin, Nall Janice. Looking to the future of new media in health marketing: deriving propositions based on traditional theories. Health Mark Q.2008;25(12):147-74. doi: 10.1080/07359680802126210. [Cross Ref]

[11] Elif Akagun Ergin \& Handan Ozdemir Akbay (2010), "Consumers' Purchase Intentions for Foreign Products: An Empirical Research Study in Istanbul, Turkey", 2010 EABR \& ETLC Conference Proceedings Dublin, Ireland.

[12] Ellison, N. B., Steinfield, C., \& Lampe, C. (2007). The benefits of Facebook "friends:" Social capital and college students' use of online social network sites. Journal of Computer-Mediated Communication, 12(4), 1143-1168.

[13] Eugene, A., Carlos, C., Debora, D., Aristides, G., \& Gilad, M. (2008), “ Finding High-Quality Content in Social Media”, Palo Alto, California, USA.

[14] Eysenbach Gunther. Medicine 2.0: social networking, collaboration, participation, apomediation, and openness. J Med Internet Res. 2008;10(3):e22.

10.2196/jmir.1030.http://www.jmir.org/2008/3/e22/v10i3e22 [PMC free article] [PubMed] [Cross Ref]

[15] General Electric. (2008). Imagination at work: Our culture.Retrieved August 25, 2008, from http://www.ge.com/company/culture/index.html

[16] Gladwell, M. (2000). The Tipping Point: How Little Things Can Make a Big Difference, first published by Little Brown. ISBN 0-316-31696-2.

[17] Goh Tiong-Thye and Yen-Pei Huang. (2009). Monitoring youth depression risk in Web 2.0. The journal of information and knowledge management systems Vol. 39 No. 3, 2009 pp. 192-202.

[18] Hassan Siddique, (2011, Jan 08) Social networking sites become advertising hub. Retrieved January 13, 2011, from http://pakistantoday.com.pk/pakistan-news/Lahore/08-Jan-2011/Socialnetworking-sites-become-advertising-hub

[19] Hean Tat Keh \&Yi Xie, (2009), "Corporate reputation and customer behavioral intentions: The roles of trust, identification and commitment", Industrial Marketing Management, 732-742.

[20] Hitwise (2007), "Social networking visits increase 11.5 percent from January to February", available at: http:/hitwise.com/presscenter/hitwiseHS2004/socialnetworkingmarch07.php (accessed 19 July 2007).

[21] Holak, Susan, Donald R. Lehmann, and Fareena Sultan (1987), "The Role of Expectations in the Adoption of Innovative Durables: Some Preliminary Results,'Journal of Retailing, 63 (Fall), 243-259.

[22] Horrigan J. Wireless Internet use. Washington, DC: Pew Internet \& American Life Project; 2009. Jul 22, [2009-0731]. webcite http://pewinternet.org/Reports/2009/12-Wireless-InternetUse.aspx.

[23] Hrsky, Dan (1990), "A Diffusion Model Incorporating Product Benefits, Price, Income, and Information," Marketing Science, 9 (Fall), 342-365. 
[24] Huffaker, D. (2006), Teen Blogs Exposed: The Private Lives of Teens Made Public, American Association for the Advancement of Science, St. Louis, MO.

[25] Jerry Wind \& Vijay Mahajan (2001), "Convergence Marketing: Strategies for Reaching the New Hybrid Consumer”, ISBN:0130650757.

[26] Jerry Wind and Vijay Mahajan (2001). Convergence Marketing: Strategies for Reaching the New Hybrid Consumer. (O2001 ISBN:0130650757

[27] Kaplan A. M., Haenlein M., (2010), "Users Of The World, Unite! The Challenges And Opportunities Of Social Media", Business Horizons, Vol.53, Issue 1.

[28] Kirmani, A. and Baumgartner, H. (2000), "Reference Points Used in Quality and Value Judgments", Marketing Letters, Vol. 11, No. 4, pp. 299-310.

[29] Lefebvre RC. The new technology: the consumer as participant rather than target audience.Social Marketing Quarterly. 2007;13(3):31-42. doi: 10.1080/15245000701544325. [Cross Ref]

[30] Lenhart, A., \& Madden, M. (2007). Teens, privacy \& online social networks: How teens manage their online identities and personal information in the age of MySpace. Washington, DC: Pew Internet \& American Life Project.

[31] Mangold W. Glynn a, Faulds David J. (2009). Social media: The new hybrid element of the promotion mix. Business Horizons (2009) 52, $357-365$

[32] Mittal, V., Kumar, P., \& Tsiros, M. (1999). Attribute-level performance, satisfaction, and behavioral intentions over time. Journal of Marketing, 63(2), 88-101.

[33] Nancy Atkinson, Wen-ying Sylvia Chou, Yvonne M Hunt, Ellen Burke Beckjord, Richard P Moser, and Bradford W Hesse. (2009). "Social Media Use in the United States: Implications for Health Communication”. J Med Internet Res. 2009 Oct-Dec; 11(4): e48.

[34] Nardi, B.A., Schiano, D.J. and Gumbrecht, M. (2004), "Blogging as social activity, or, would you let 900 million people read your diary?", Proceedings of the 2004 ACM Conference on Computer Supported Cooperative Work, Chicago, IL, ACM Press, New York, NY, pp. 22231.

[35] Nielsen//NetRatings (2006, May 11). Social networking sites grow 47 percent, year over year, reaching 45 percent of web users, according to Nielsen//NetRatings. Retrieved August 30, 2007, from http://www.nielsen-netratings.com/pr/pr_060511.pdf

[36] Pakistan Telecommunication Authority http://www.pta.gov.pk/index.php?cur_t=vtext\&option=com_content\&tas $\mathrm{k}=\mathrm{view} \& \mathrm{id}=583 \& \mathrm{Itemid}=1 \& \mathrm{catid}=95$, Retrieved on January 20, 2011.

[37] Pascu, C., Osimo, D., Turlea, G., Ulbrich, M., Punie, Y. and Burgelman, J-C. (2008), "Social computing: implications for the EU innovation landscape", Foresight, Vol. 10 No. 1, pp. 37-52/

[38] Pempek Tiffany A., Yevdokiya A. Yermolayeva and Sandra L. Calvert. (2009). College students' social networking experiences on Facebook. Journal of Applied Developmental Psychology 30 (2009) 227-238.

[39] Procter and Gamble. (2008). Purpose, values, and principles. Retrieved August 25, 2008, from http://www.pg.com/company/who_we_are/ppv.shtml

[40] Rao, A. R. and Monroe, K. B. (1989), "The Effect of Price, Brand Name, and Store Name on Buyers' Perceptions of Product Quality: An Integrative Review", Journal of Marketing Research, Vol. 26, pp. 351357.

[41] Robert, A. P., Sridhar, B., \& Bronnenberg, B. J. (1997). Exploring the implications of the internet for consumer marketing. Journal of the Academy of Marketing Science .

[42] SCOTT David (2007), "The new rules of marketing and pr : how to use news releases, blogs, podcasting, viral marketing and online media to reach buyers directly".

[43] Suziki, L., \& Calzo, J. (2004). The search for peer advice in cyberspace: An examination of online teen bulletin boards about health and sexuality. Journal of Applied Developmental Psychology, 25, 685-698.

[44] Tiffany A. Pempek, Yevdokiya A. Yermolayeva \& Sandra L. Calvert (2009), "College students' social networking experiences on Facebook", Journal of Applied Developmental Psychology, 227-238.
[45] Tiong-Thye Goh \& Yen-Pei Huang (2009), "Monitoring youth depression risk in Web 2.0", The journal of information and knowledge management systems Emerald Group Publishing Limited, 192-202.

[46] Toivonen, S. (2007), Web on the Move. Landscapes of Mobile Social Media, VTT Research Notes 2403, Espoo.

[47] Toni Ahlqvist, Asta Ba“ck, Sirkka Heinonen \& Minna Halonen (2009), "Road-mapping the societal transformation potential of social media", Emerald Group Publishing, 3-26.

[48] Turney, P.D. and Littman, M.L. (2003), "Measuring praise and criticism: inference of semantic orientation from association", ACM Trans. Inf. Syst., Vol. 21 No. 4, pp. 315-46.

[49] W. Glynn Mangold \& David J. Faulds (2009), "Social media: The new hybrid element of the promotion mix", Business Horizons, Science Direct, 357-365.

[50] Wikipedia, http://en.wikipedia.org/wiki/Telecommunications_in_Pakistan, Retrieved on January 20, 201.

[51] Zeithaml, V. A., Berry, L. L., \& Parasuraman, A. (1996). The behavioral consequences of service quality. Journal of Marketing, 60(2), 31-46.

[52] G. Eason, B. Noble, and I. N. Sneddon, "On certain integrals of Lipschitz-Hankel type involving products of Bessel functions," Phil. Trans. Roy. Soc. London, vol. A247, pp. 529-551, April 1955. (references)

[53] J. Clerk Maxwell, A Treatise on Electricity and Magnetism, 3rd ed., vol. 2. Oxford: Clarendon, 1892, pp.68-73.

[54] I. S. Jacobs and C. P. Bean, "Fine particles, thin films and exchange anisotropy," in Magnetism, vol. III, G. T. Rado and H. Suhl, Eds. New York: Academic, 1963, pp. 271-350.

[55] K. Elissa, "Title of paper if known," unpublished.

[56] R. Nicole, "Title of paper with only first word capitalized," J. Name Stand. Abbrev., in press.

[57] Y. Yorozu, M. Hirano, K. Oka, and Y. Tagawa, "Electron spectroscopy studies on magneto-optical media and plastic substrate interface," IEEE Transl. J. Magn. Japan, vol. 2, pp. 740-741, August 1987 [Digests 9th Annual Conf. Magnetics Japan, p. 301, 1982].

[58] M. Young, The Technical Writer's Handbook. Mill Valley, CA: University Science, 1989.

\section{Authors PROFILE}

Mahmood Rehmani is a student of Master of Science with major in Marketing at Department of Management Sciences, Mohammad Ali Jinnah University, Islamabad, Pakistan. He is also working as Public Relation Officer with Pakistan Engineering Council. Major duties include handling newsletters, Enewsletters, online groups, facebook fan page, twitter and production of audio video material for better corporate image of Pakistan Engineering Council. Mahmood is President of Islamabad Chapter of Pakistan Council for Public Relations and also voluntarily providing Media Consultancy services to Knowledge \& Information Management Society (KIMS), Human Advancement Network for the Deprived (HAND) and Women In EnergyPakistan.

Muhammad Ishfaq Khan is supervisor and faculty member at Department of Management Sciences, Mohammad Ali Jinnah University, Islamabad. He has been teaching since 2003. During his teaching tenure, Mr. Khan delivered lectures in different degree awarding institutions like COMSATS Institute of Information Technology, Islamabad Campus, Quaid-e-Azam University, Islamabad, Mohammad Ali Jinnah University, Islamabad Campus, Riphah International University, Islamabad. Mr. Khan has submitted his research thesis at COMSATS Institute of Information Technology, Islamabad. Before this, He has completed his Master of Science in Management Sciences from COMSATS Institute of Information Technology, Islamabad. In addition, He has done his Master of Business Administration from Mohammad Ali Jinnah University, Islamabad Campus. Furthermore, Mr. Khan has received a Post Graduate Diploma in Computer Science from International Islamic University, Islamabad. Mr. Khan has more than 20 research publications in peer reviewed journals, national and international conferences. (Boston, Florida, Singapore, Japan, Hong Kong, Malaysia, Spain, New York, Australia and Pakistan. 